\title{
The Rules of the Game: Feminist Policymaking in Chile
}

Liesl HAAS

$\mathrm{T}$

he fact that it is me who is here tonight is a symbol of the change we have lived. We leave behind many fears and prejudices. Today Chilean society is more open, more tolerant, more diverse. People don't want only the right to vote, but also the right to have a voice. They want to be heard. They want to forge their own destiny. In my government we will provide a channel for this desire for participation. We will forge a great alliance between politics and society, between representatives and the represented. (Victory speech by president-elect Dr. Michelle Bachelet, Santiago, Chile, January 15, 2006)

The election of Socialist Michelle Bachelet to the Chilean presidency has enormous importance -both symbolic and practical- for Chilean women and their ongoing struggle for full citizenship and equal rights. An avowed feminist, she signifies the progress that Chilean women have made since the transition to democracy in legitimizing issues of women's rights and in gaining greater political voice. She has already demonstrated her commitment to expanding the gains Chilean women have made to date to by appointing of a cabinet that is $50 \%$ female and signaling her support for a positive discrimination law that would boost women's representation in the Congress. In many ways, Michelle Bachelet's political success would seem to represent the public face of a deeper transformation of women's status in Chilean society. This study evaluates that conclusion by analyzing the progress Chilean women have gained since the end of authoritarian rule in implementing the political goals of the feminist movement and expanding women's legal rights.

Thousands of Chilean women risked their lives fighting for a return to democracy. To what extend did the democracy they get reward their efforts? Much of the existing research on women and politics in Chile emphasizes the ways that Chilean democracy has fallen short of the 
expectations of the feminist movement ${ }^{1}$. A number of scholars emphasize the political dissolution of the feminist movement and the women's movement more broadly (Alvarez, 1999; Matear, 1997), which has dramatically reduced the visibility of feminism as a source of political pressure for policy reform. While some of the factors reducing the movement's political influence are internal in nature ${ }^{2}$, scholars have also pointed out the ways in which the democratic transition itself and the institutional political structure that resulted have served to undermine women's participation and to limit the opportunities for farreaching policy reforms (Alvarez, 1999; Waylen, 1993; Ríos Tobar, 2003). Although the creation of Sernam (Servicio Nacional de la Mujer), a cabinetlevel women's rights agency, represents a permanent location for women's rights advocacy within the state, both members of feminist organizations and feminist representatives in Congress lament their secondary role in Sernam's policymaking efforts (Richards, 2003, 2004; Franceschet, 2003; Schild, 1998; Waylen, 1996).

Yet there have also been a number of important advances in women's rights since the transition to democracy. Sernam and feminist representatives in Congress have spearheaded a broad range of policy proposals expanding women's equality, touching on education, health, political representation, employment, day care, marital law, and the constitution. Among these proposals are some notable successes, such as the passage of legislation on domestic violence, sexual assault, day care, employment discrimination and divorce. Women's political representation, while low, is on the rise across political parties, and support for a national quota law is increasing. Perhaps more significantly, congressional support for feminist policy proposals has diffused beyond the small core of feminist representatives who initiated the majority of proposals in the first democratic administrations. The same literature that notes the political disintegration of the feminist movement also acknowledges the wide diffusion of feminist ideals throughout Chilean society - in the media, universities, political parties, and public opinion (Ríos Tobar, 2003).

How can we make sense of the conflicting characterizations of the state of women's rights in Chile? In this article, I analyze the progress Chilean women have made since the transition to democracy by focusing on what is inarguably a core component of progress on women's rights: the

1. The feminist movement, which is a subset of the broader women's movement, seeks the transformation of the system of gender domination. As there is no single, unified feminist community in Chile, most scholars speak of "feminisms" or feminist movements. See Frohman and Valdés 1993, Alvarez 1998, Baldez 1999, Ríos 2003, Blofield and Haas 2005.

2. A number of factors have negatively affected the feminist community since the transition to democracy, including financial difficulties, exhaustion and lack of generational replacement, a depletion of leadership to political parties, and difficulty strategizing movement activism to fit the democratic political context. 
passage of legislation that promotes the goals of the feminist movement. While the passage of legislation is, of course, not the only test of a society's openness to women's rights, it is undeniably a critical component of any larger program of political, cultural and economic transformation of women's status. The feminist movement that arose under the dictatorship (1973-1989) articulated a well-developed agenda for political change, and the political parties vying for representation in the new government promised to respond to these concerns. To what extent did democracy allow feminists to achieve political change and implement the demands they had developed over the previous sixteen years? By looking at legislative attempts to promote women's equality, we are able to examine the political responsiveness of the Chilean government to citizen claims for equal treatment, which goes to the heart of democratization.

\section{The Feminist Policy Agenda}

Feminist legislation seeks to eliminate all forms of economic, political, social and cultural inequalities between women and men. It thus seeks women's full and equitable incorporation as citizens. Drawing on the policy agenda developed by the feminist community under the dictatorship, early in the first post-transition democratic administration congressional advocates for women's rights ${ }^{3}$ and the leadership of Sernam began development of a wide-ranging policy agenda, touching on a number of critical issues of women's rights. Over the past sixteen

3. Congressional advocates for women's rights include several representatives who selfidentify as feminist and have strong connections to the feminist movement in Chile. Many of the first feminist policy proposals following the transition were spearheaded by these representatives, most notably Deputies Adriana Muñoz (PS, later PPD), María Antonieta Saa (PPD), Laura Rodriguez (PH) and Senator (and, later, Deputy) Laura Soto (PPD). Other women representatives from the Left, such as Isabel Allende (PS), had weaker links with organized feminist groups but were consistent advocates of feminist legislation in the Congress and described themselves as feminists. Finally, women representatives from the PDC, such as Deputy Mariana Aylwin and Senator Carmen Frei, were reluctant to embrace the label "feminist" because of resistance to the term among sectors of their party, but both were strong proponents of feminist legislation, and Aylwin, in particular, spearheaded or co-signed numerous feminist policy proposals, most notably the success effort to legalize divorce. Each of these representatives emphasized in interviews with the author that they considered women's rights a central policy concern. Since the transition, women representatives from RN have, to varying degrees, also shown support for some feminist policy issues. While their support is not consistent, and while these representatives reject the label "feminist", their degree of participation in the development of feminist policy proposals far outpaces that of their party in general and is an indication of the growing influence of feminism beyond its base within the Left. For purposes of this analysis, these latter representatives are not considered feminist, due to their explicit rejection of the label and inconsistent support for feminist policy, but their growing political support for feminist proposals is evident in the higher number of bills introduced by a Left-Right alliance in recent years (see Table 1). 


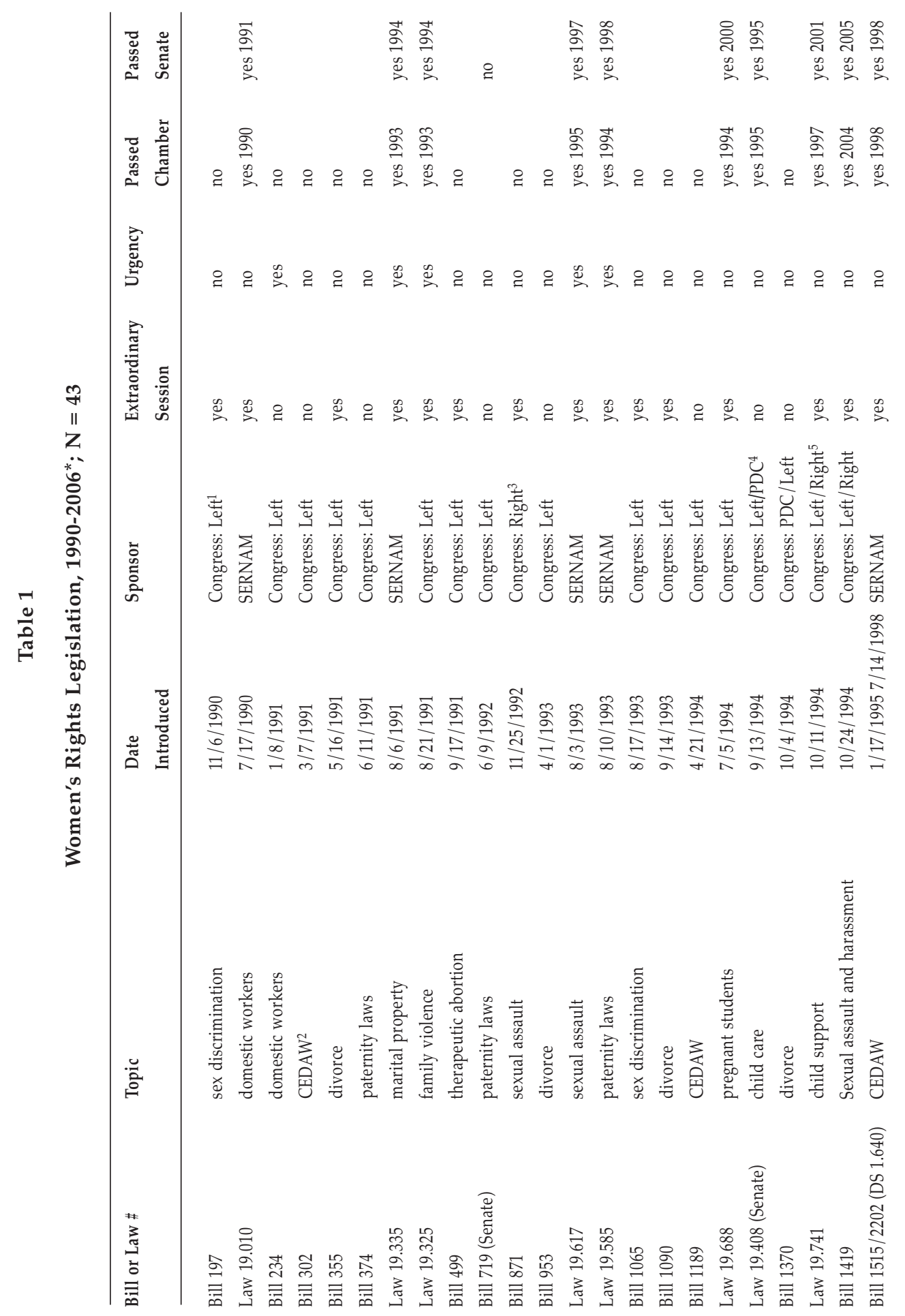




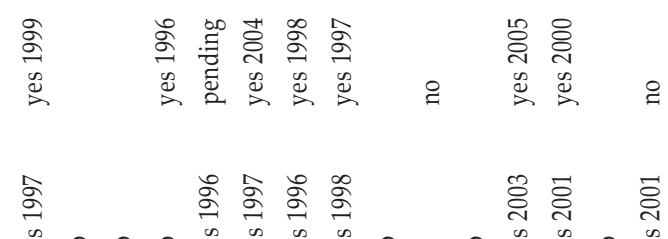

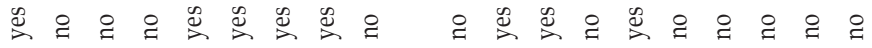

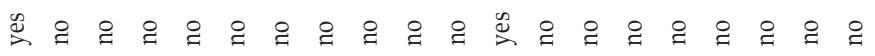

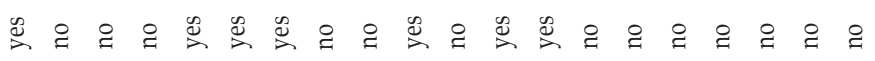

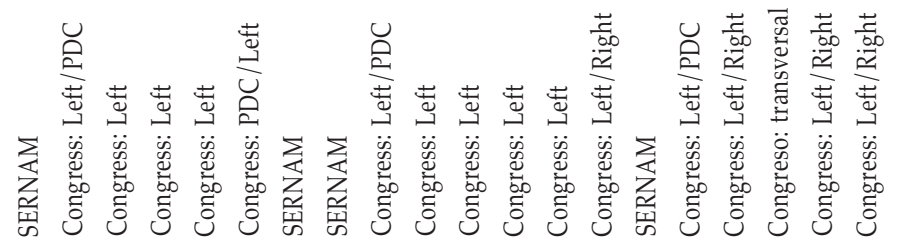

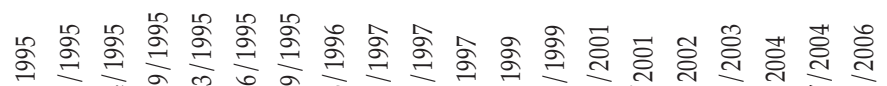

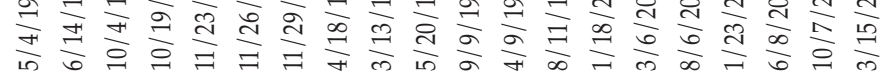

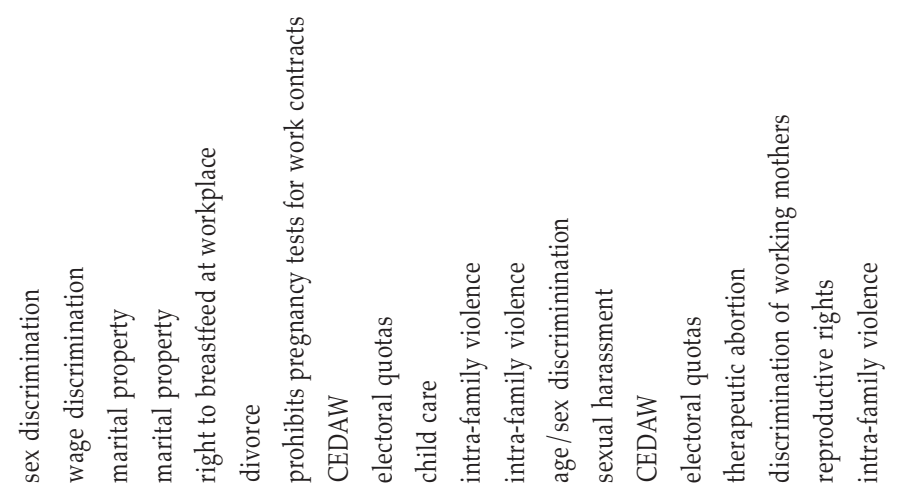

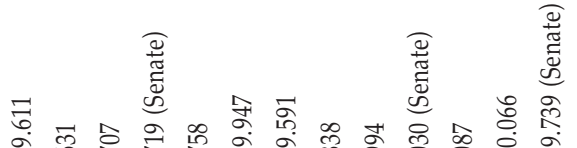

荑

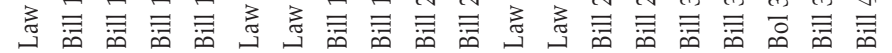

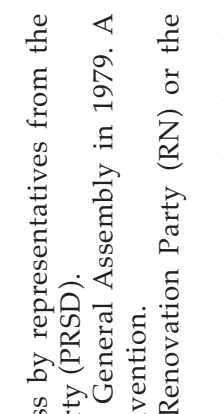

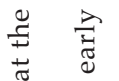

क

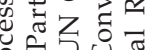

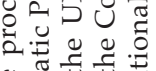

焉声声要

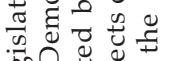

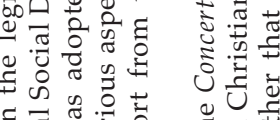

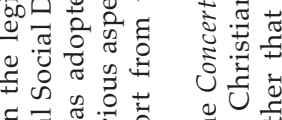

๘ ङ

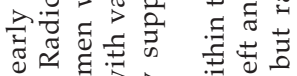

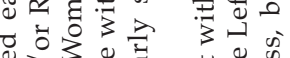

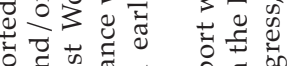

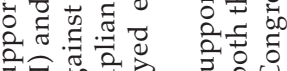

के

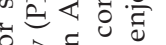

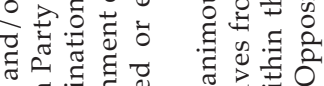
空

उ

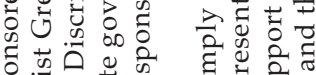

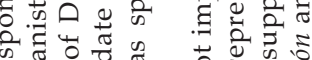

की

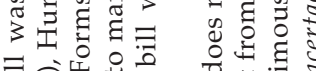

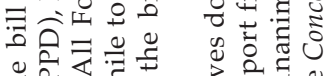

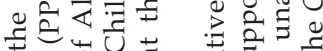

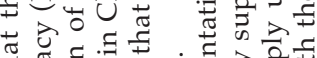

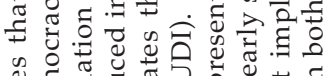

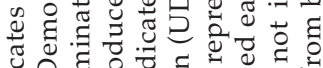
ฮั

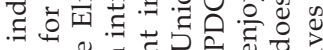

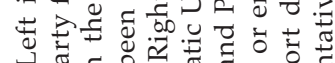

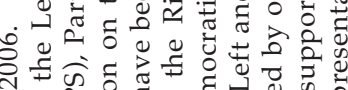

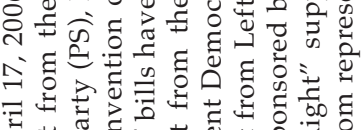

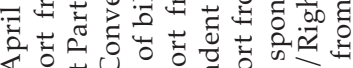

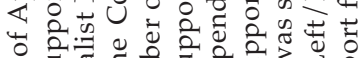

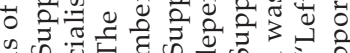

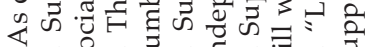


years, forty-two legislative proposals have been introduced to expand women's legal equality, across policy areas as diverse as the rights of domestic workers, intra-family violence, sexual harassment and assault, sex and wage discrimination, the educational rights of pregnant students, protections for pregnant workers, day care, paternity law, marital property rights, therapeutic abortion and divorce ${ }^{4}$.

Keeping in mind the often glacial pace of legislative reform, a number of observations can be made from an initial analysis of the universe of women's rights legislation. To begin, the range of policy proposals is impressively broad. It is also apparent that, while the majority of proposals were introduced by congressional representatives, Sernam has enjoyed a much higher success rate with its own legislative projects ${ }^{5}$. Eight of nine bills introduced by Sernam eventually became law, whereas, between 1990 and 20016, only eight out of thirty-eight congressional bills were successful. It is worth noting that Sernam's bills were often successful where congressional efforts on the same topic had failed. This was the case, for example, with bills on sex discrimination, paternity laws, and marital property rights. Considering the range of topics covered by congressional versus executive bills, it is clear that the most controversial proposals - namely, abortion and divorce- which have been the subject of multiple proposals, have only been introduced by congressional representatives. Despite the overall low success rate of congressional bills, they enjoyed greater success beginning in the second administration (1994-2000). This corresponds with an increase in crossparty sponsorship of the bills. Furthermore, the pace of legislative action increased after 2000. This is evident both in the passage of legislation that had been dormant for many years and in the introduction of new proposals. Finally, the last few years have witnessed the reintroduction of legislative proposals on reproductive rights and abortion, arguably the most politically controversial women's rights issues.

4. These topics have been introduced as legislation in various forms, some narrowly focused and some more sweeping in scope, but all the bills defined as feminist in this study deal with topics first advocated by the feminist community. As the ideals of feminism diffuse beyond an original group of self-defined activists and the importance of women's equality becomes more accepted culturally and politically, we should not be surprised to see legislation that is feminist in character supported, or even drafted, by representatives beyond the narrowly-defined feminist community. Therefore, defining legislation as feminist is not reducible simply to whether or not all the representatives who introduce a particular bill self-define as feminist nor the degree to which feminists outside the state publicly demonstrate in support of every bill. Rather, the identification of a bill as feminist rests on the character and goal of the legislation itself, which must aim to eliminate some form of discrimination (political, economic, etc.) faced by Chilean women.

5. This parallels the larger dynamic of Chilean legislation, where executive proposals are more successful than congressional efforts. See Siavelis 2000.

6 . Given the slow pace of the legislative process, I have limited my comparison of success rates of congressional bills to those introduced in 2001 or before. 
Beyond the mere fact of bill passage or failure, it is important consider the alterations that a bill may undergo in order for it to garner enough political support for passage. Some bills pass the Congress in a form relatively faithful to their original composition; others are radically transformed through negotiation and compromise and ultimately "succeed" in a version counterproductive to the original vision of the bill's supporters. To what degree have the women's rights bills that have passed the Congress done so in a version that truly signals a victory for feminists? Because space considerations do not allow for a detailed examination of every piece of feminist legislation that passed the Congress, this analysis focuses on the three bills that most clearly illustrate both the range of success among feminist policy initiatives as well as the political dynamics that govern negotiation on feminist bills.

I argue that two primary factors impact the success of feminist policy proposals: the institutional structure of the Chilean political system, which mitigates against cooperative policymaking between the Executive and Congress, and the strength of the conservative opposition to women's rights, which enjoys disproportionate political influence within the political system. While both the rigidity and undemocratic nature of Chile's political institutions and the continued strength of conservative cultural forces have been widely discussed in the literature, existing research tends to treat both as largely static forces. By contrast, an examination of feminist policymaking reveals a political environment that is highly dynamic. Over the past sixteen years, feminists within the political system have learned to navigate more effectively within this challenging institutional and cultural context. The three policy case studies discussed below -domestic violence, therapeutic abortion, and divorce- illustrate the evolving political strategies of advocates for women's rights, which have led to increased success in passing feminist legislation.

\section{Institutional Cooperation}

Political parties in Chile span the ideological spectrum and have deep historical roots and relatively stable electoral constituencies. However, the change to a binomial electoral system following the transition had the effect of forcing the parties to form broad electoral coalitions. Parties of the Center-Left joined together in the Concertación coalition, which has governed Chile since the transition. The parties of the Right formed an alternative electoral coalition.

From 1990-2000, the Christian Democratic Party held the presidency (Patricio Aylwin, 1990-4; Eduardo Frei, 1994-2000). In 2000, Socialist Ricardo Lagos was elected President, followed by Socialist Michelle Bachelet (2006-). The cohabitation of distinct ideological tendencies 


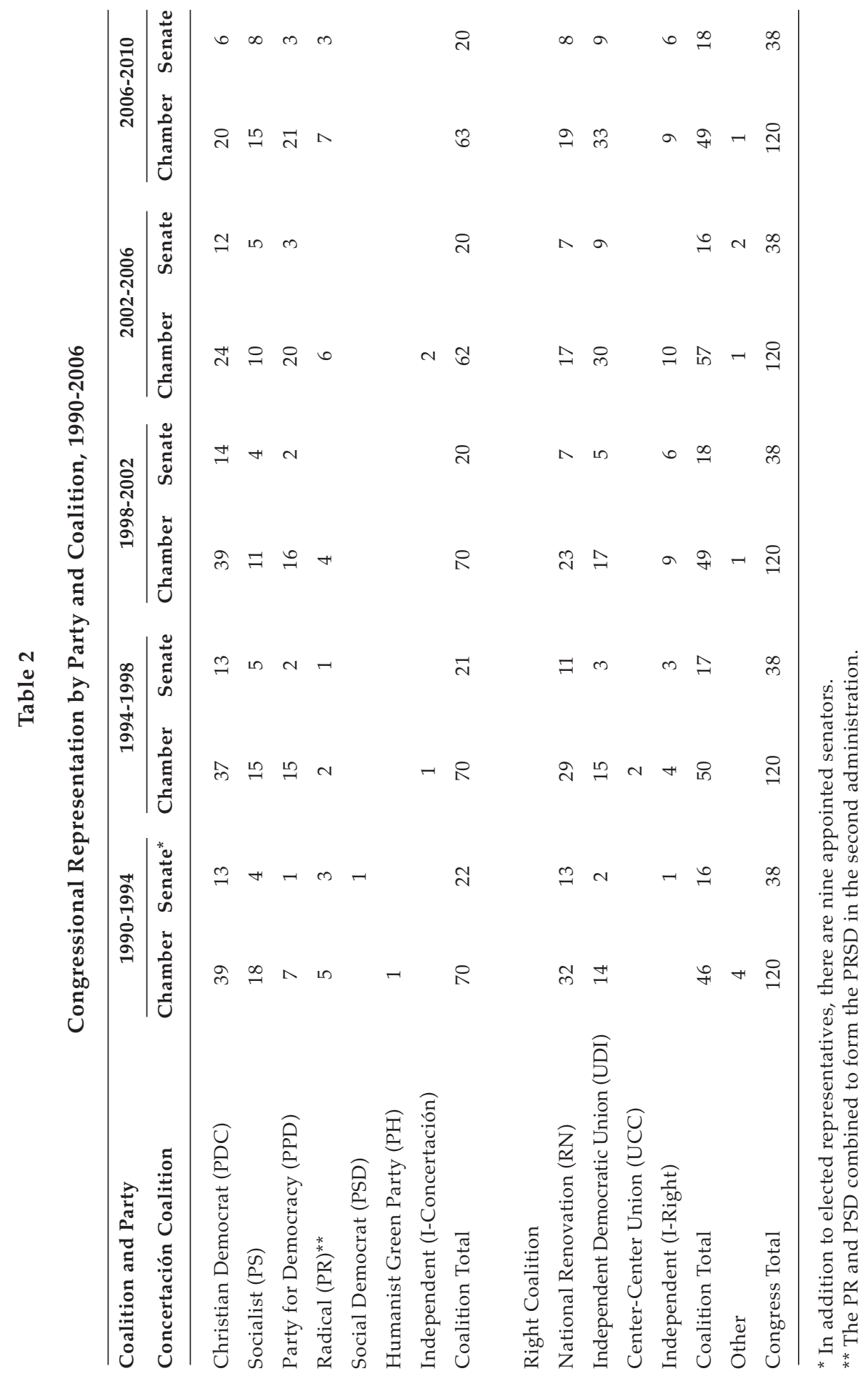


within the governing coalition has meant that individual parties must balance their own policy preferences against the larger needs of the coalition (Siavelis, 2000). In the case of women's rights legislation, the Left is largely unified in support of most feminist proposals, but this support must be balanced against divisions on these issues within the PDC. The Christian Democratic Party is reluctant to promote policy reforms on issues that will bring it into conflict with the Catholic Church (Blofield and Haas, 2005; Haas, 2000)7. The obstacles to reform are greater in the Senate, where the institutional Senators and the Left's overall lower representation in the upper house have served to block or stall many feminist proposals that managed to pass the Chamber of Deputies.

Cooperation on policy is further complicated by the power of the executive branch, which plays a dominant role in the legislative process. Formal executive powers include the ability to determine the legislative agenda for the majority of the year and exclusive legislative jurisdiction over a number of crucial areas, including budgetmaking. The Executive also has the power to declare a bill "urgent", which keeps it alive in committee and encourages congressional debate on the proposal. Arguably of equal importance in the policymaking process are the informal powers of the executive branch. The Executive counts with considerably greater financial resources than representatives and also has an extensive legislative staff. This allows Executive ministries to develop bills that are often technically superior than similar congressional proposals. In addition, informal rules of procedure allow members of the Executive to participate in congressional committee meetings (Siavelis, 2000; Baldez and Carey, 1999). In the case of women's rights legislation, this allows Sernam to craft a persuasive proposal and to monitor it closely throughout the review process, while the authors of congressional bills are often shut out from the relevant review committees (Blofield and Haas, 2005).

The institutional strength of Sernam, as part of the Executive, presents advantages and disadvantages for attempts to promote feminist policy. The ideological orientation of the Ministry under a particular administration is an important consideration (Baldez, 2001), as is the personality of particular ministers (Haas, 2000). During the first democratic administration, Sernam was headed by Christian Democrat Soledad Alvear, who pursued an aggressive policy agenda and promoted a number of legislative proposals. However, research notes that this particular period was also characterized by a very moderate

7. Due to its outspoken defense of human rights under the dictatorship, the Church enjoyed renewed political influence following the transition to democracy. It has attempted to parlay this into influence over the policy agenda, where it strongly opposes policy reform on many feminist issues (Blofield 2006, Haas 1999). 
approach to the content of legislative proposals as well as a tendency to develop legislative proposals in isolation from congressional representatives and members of the feminist community (Htun, 2003; Baldez, 2001; Valenzuela, 1999; Waylen, 1997) ${ }^{8}$ Under the leadership of Minister Josefina Bilbao (PDC, 1994-2000), Sernam spoke out forcefully on a number of feminist policy issues and increased its support for congressional proposals, but it stopped short of supporting the decriminalization of therapeutic abortion or the legalization of divorce. Feminists hoped that under a Socialist administration, and with a change in the party leadership of Sernam, progress would be made on the more contentious feminist policy proposals, but the appointment of PPD Minister Adriana del Piano (2000-2003) initially disappointed feminists by reasserting a commitment to less divisive political issues (Ríos Tobar 2003). In the latter part of del Piano's term at Sernam, the Ministry shifted to an outspoken support of divorce legislation, and this continued with the appointment of Cecilia Pérez (Independent) in 2003. Pérez also pushed for the resolution of legislative initiatives that had stalled in the Senate. Initial indications are that Laura Albornoz (PDC), President Bachelet's appointee to head the Ministry, envisions an ambitious policy role for the Sernam. She has already signaled her intention to renew debate on an electoral quota law that would boost women's representation in the Congress.

Regardless of a particular Minister's degree of openness to feminist policymaking, congressional representatives still retain incentives to promote their own legislative initiatives on women's rights. Feminist representatives must balance loyalty to their party and constituency concerns against a desire to pursue feminist policy reforms. If representatives lose "ownership" of a bill to Sernam, they lose control over the bill's content, and they can no longer claim credit for the resulting legislation. Therefore, while recognizing the advantages that come from executive sponsorship of legislation, feminist representatives still struggle to maintain an independent legislative agenda. The ability of advocates of women's rights to pursue controversial policy reform in the absence of executive sponsorship is further complicated by women's overall low representation in the legislature ${ }^{9}$.

8. Researchers have suggested that Sernam's desire to control the legislative agenda on women's rights came in part from its desire to assert its influence within the larger bureaucracy (Nikki Craske 1999; Ann Matear 1996; Fiona Macauley 1998; Georgina Waylen 1997).

9. While not all women representatives are feminist, the number of women representatives is nevertheless significant because women are overall more likely to express interest in issues concerning women, relative to male representatives of their party. In the Chilean case, for example, where support for feminist legislation has expanded beyond the Concertación, it has first won the support of women representatives from RN, such as María Angélica Cristi, Lily Pérez and Marina Prochelle. 
The Rules of the Game: Feminist Policymaking in Chile 209

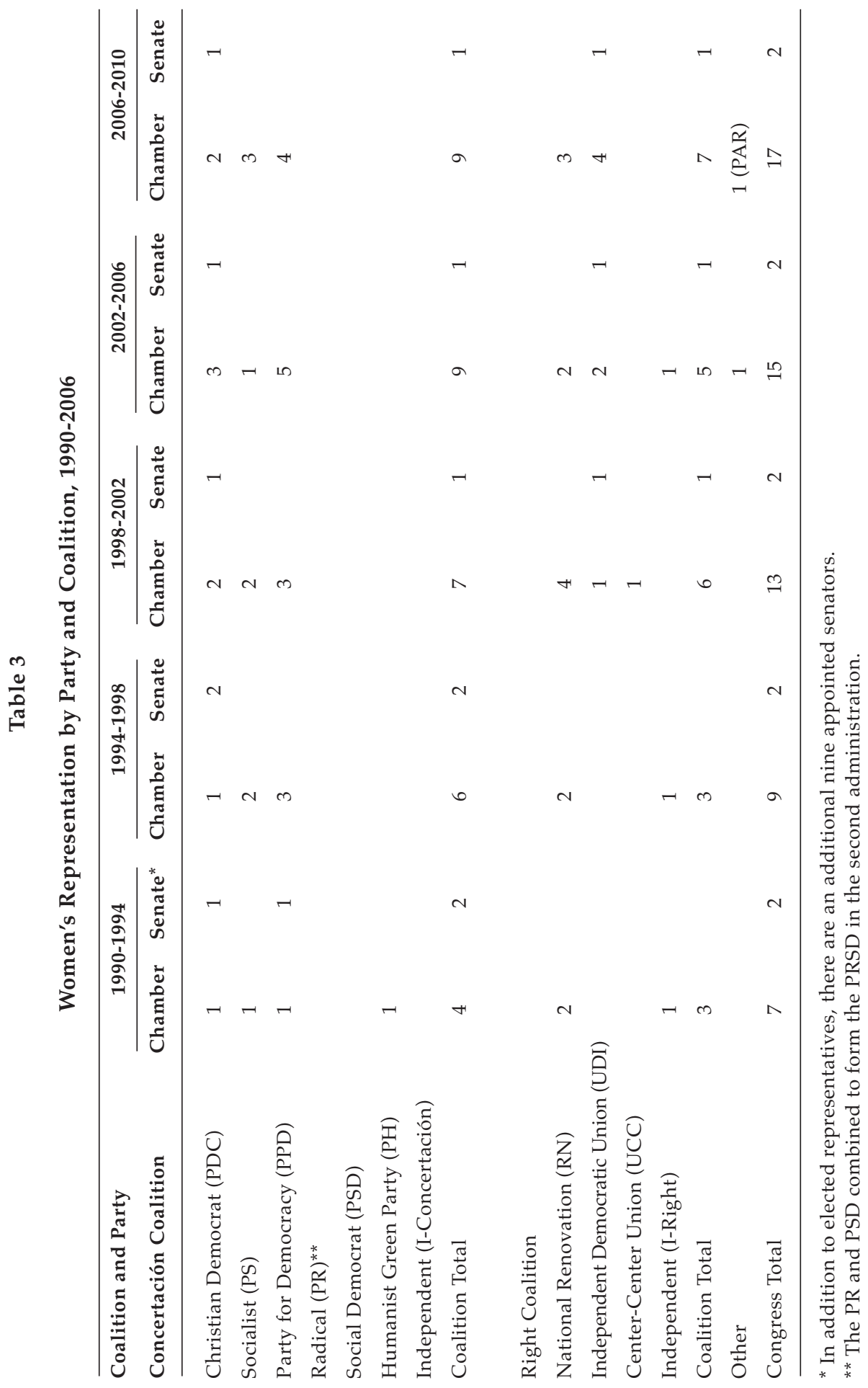


In critical ways, therefore, the Chilean system works against institutional cooperation. When feminist policymakers succeed in overcoming these obstacles, they must still confront the larger cultural opposition to feminist that blocks attempts to reform laws on women's rights. Feminist policymakers must attempt to frame their proposals in a way that reduces this opposition and to negotiate the content of their bills to try to gain support for passage. However, these strategies may exact a high cost in terms of the integrity of the original proposals.

\title{
Strategic Framing
}

In their analysis of the class and gender cleavages in women's rights legislation in Chile, Blofield and Haas (2005: 2-3) explain:

\begin{abstract}
Support for or opposition to reform on women's rights is only partially linked to the economic left-right dimension. It also touches on deeply held beliefs about women's roles within the family and their participation in society. Conservative discourse tends to characterize the traditional family and the different social roles of men and women within it to be the natural, complementary outgrowth of the biological differences between women and men. Conservative social and political actors thus oppose proposals that aim to rebalance this traditional structure. By contrast, feminist research focuses on the ways traditional conceptions of the family disadvantage women (for example, through women's double labor burden, their social and legal inequality within marriage, and their economic dependency on men). For this reason, feminists often frame their arguments in terms of women's individual rights, and the primacy of these individual rights over the socially constructed obligations connected to the roles of wife, mother, etc. These arguments are often reflected in policy proposals by the Left (and to a lesser degree, the political center).
\end{abstract}

In the absence of executive support for legislation, congressional representatives need to build a broad base of support for their legislation earlier in the process. In a political environment where conservative parties maintain a strong electoral presence and the Catholic Church is an influential force in shaping public discourse on controversial social issues, feminist policymakers' ability to strategically frame policy proposals becomes a critical factor for passage. This has led to one of the most important characteristics of successful congressional legislation on women's rights: the conscious moderation of a bill's framing and content to appeal to congressional conservatives. On a wide-ranging number of issues, including domestic violence, day care, paternity, divorce and abortion, feminists attempted defend their proposals on the basis of what was good for the family as a whole. As explained by Adriana Muñoz:

There's a modification of the language, of the focus. There was an attempt to "de-radicalize" the issue [of women's rights] because we 
understood that there was an entrenched rejection from the Right, and also from the political center, also from the Christian Democrats, who have rejected "women's issues", stigmatizing them as feminist, ultraradical and anti-system ${ }^{10}$.

While feminists can count on the Left parties to be generally supportive of most feminist policy proposals, they must consider the degree of controversy a proposal is likely to cause within the PDC. As is evident in Table 2, near unanimity is required within the Concertación for a proposal to have a chance of passage. In some cases, moderate representatives have signed onto feminist legislation, counterbalancing the opposition of conservative Christian Democrats. The more controversial the bill the more critical presentation of the proposal becomes. As illustrated in the case studies that follow, it is on the most controversial bills that feminists make the most concerted effort to link their support to a concern for the family. This has led to a re-evaluation by feminist legislators of the possibility of radical legislative change. Deputy Muñoz concludes, "Now I think we've achieved things, but we've achieved them a la chilena as we always say, very slowly, so no one notices"11.

This "culture of accommodation" (Grau, 1997) has been criticized by many feminists, who argue that it cedes too much political ground to political conservatives. Feminists inside and outside the state debate the point at which "something becomes worse than nothing". As explained by a member of La Morada, a feminist NGO that has closely monitored policy developments on women's rights:

I don't believe that something is better than nothing. I thought so at one time, when I believed that compromise was necessary, [but now] I believe that one can go on supporting what one believes in... The discourse of the Right will be the same, whether we keep quiet or declare our differences. The discourse of the Right is the discourse of the traditional Catholic Church, and it's not only the Right, I think there are also a lot of progressive groups that employ the same discourse ${ }^{12}$.

María Elena Valenzuela, a long-time member of the women's movement who later worked at Sernam, similarly argues that the idea of consensus in Chile does not imply a negotiation of political differences, but rather the avoidance of divisive issues at all costs, as illustrated by the intrafamily violence bill:

In practice, "consensus" means that we're going to behave as though we have no differences. We're not going to negotiate our differences, what doesn't unite. We're going to make agreements based on what we agree upon, and the other things, we'll almost act as if they don't exist. And women's rights is an issue that divides. So we're going to work out an agreement on this issue as if we didn't think so differently... So for this

10. Interview with the author, June 5, 2001.

11. Interview with the author, June 5, 2001.

12. Author's interview with Veronica Matus, January 9, 1997. 
reason you'll often encounter situations that really don't satisfy anyone, instead of arriving at something that is the fruit of all of us ${ }^{13}$.

There are, therefore, limits to strategic framing and negotiation of feminist proposals. The point at which a proposal for reform becomes "worse than nothing" was debated in each of the case studies detailed below.

\section{Case Studies}

While my theory of feminist policymaking emerges from an examination of all feminist legislative bills introduced between 1990 and 2002, I utilize three particular case studies in this article to illustrate my argument: the 1994 Intra-Family Violence Law (introduced in 1991); the (unsuccessful) Therapeutic Abortion bill (introduced in 1991); and the 2004 Divorce Law (introduced in 1995). Why these case studies? All three are important issues for the feminist community. They have each been the subject of multiple legislative proposals, but have met with varying success. Each has a distinct dynamic on the two main explanatory factors: institutional cooperation and strategic framing. As a result, each had a different trajectory and outcome. Finally, the dynamic of each one influenced the subsequent strategies used on later bills. In sum, this is a story about political learning, and how feminists learned to maneuver within challenging institutional and cultural terrain.

\section{Domestic Violence}

\section{Significance of the Bill}

The Intra-Family Violence Law (VIF) illustrates the often difficult institutional relationship between the leadership of Sernam and feminists in Congress, as they attempt to initiate their own policy agendas. Competition between the Minister of Sernam and congressional representatives over ownership of domestic violence legislation led to poor institutional cooperation on the bill. Congressional representatives and members of the movement blamed the Ministry for weaknesses in the resulting Intra-Family Violence law. Cultural opposition to domestic violence legislation was lower than on the other proposals examined here but was still a factor in the final shape of the legislation, which lacked the necessary funding and was weak on victim protection and on sanctions for abusers. In this case, moderate institutional cooperation and moderate strategic framing led to only moderate success - the bill passed but in a form that was widely criticized on content. A decade

13. Interview with the author, January 9, 1997. 
after the passage of the law, an improved institutional relationship between the leadership of Sernam and congressional feminists led to a successful effort to improve the VIF law.

\section{Institutional Cooperation}

Violence against women was a central policy issue for the women's movement. Feminists succeeded in calling attention to the issue of violence against women and in connecting it with the broader issues of human rights and regime violence ${ }^{14}$. Following the transition to democracy, both the newly created National Women's Ministry (Sernam) and feminist representatives developed legislative proposals on the issue of domestic violence. Socialist Deputies Adriana Muñoz and Sergio Aguiló introduced the first domestic violence bill in September 1990. They defined "domestic violence," as "that which, [even] without leaving marks or bruises, abuses in deed or word one's father, mother, or child, be they legitimate or illegitimate, or any other relative, a spouse or domestic partner"15. The bill included all family members in its definition of domestic violence, but the details of the bill were specifically focused on the physical and psychological abuse of women by their husbands or partners, which constituted the majority of cases of family violence ${ }^{16}$.

The only sanction in force at the time required non-family witnesses and physical evidence of injury to take action against the aggressor. The law also failed to provide for the immediate removal of the accused aggressor from the home once a complaint had been filed. The question of how much protection the law needed to give to victims of abuse was complicated by the fact that shelters for abused women were (and continue to be) almost non-existent in Chile. The bill allowed for anyone with direct knowledge of abuse to file a complaint, it instituted the means for removing the aggressor from the home, effecting a restraining order for place of work or school, and it set up a system of family support for the period in which the aggressor was away from the home. The bill indicated that therapy for the aggressor would be a mandatory component of any program of rehabilitation, together with options for prison sentences, fines, and community service work for the municipality.

The start of the extraordinary legislative session forced Deputies Muñoz and Aguiló to seek executive sponsorship from Sernam for the bill.

14. This linkage is illustrated by the now famous demand of the women's movement in Chile, "Democracy in the country and in the home" (See Frohmann and Valdés, 1993).

15. Bill 451-07, Article 1, cited in Legislative session 32a, p. 3170, August 21, 1991.

16. The bill noted that fully $76 \%$ of abuse in Chile was by men toward women ("La Mujer Maltratada" cited on p. 2626, session 30a, December 15, 1992). 
However, in January 1991, Sernam introduced a bill on domestic violence into Congress as an executive proposal. Sernam's bill on "intrafamily violence" closely resembled the joint proposal that had been negotiated between the Ministry and Deputies Muñoz and Aguiló17. Following protests by Deputies Muñoz and Aguiló ${ }^{18}$, Sernam agreed to withdraw its bill in favor of the original congressional proposal, but insisted on an active role for itself in the amendment process in return for sponsorship.

While Sernam's intense involvement in the shaping of the legislation was resented by some of the bill's supporters, this executive sponsorship also brought with it clear political advantages. None of the bill's congressional sponsors sat on the committees that would debate the bill, but Sernam Minister Alvear had permanent access to the committees and invited Deputies Muñoz and Aguiló to accompany the Ministry's legal team to the hearings on the bill, in both the Chamber of Deputies and later in the joint committees that would resolve differences between the Chamber and Senate versions of the bill. In addition, Sernam invited members of key feminist organizations working on violence against women to testify before the committees and submit data on the issue of domestic violence for the committee reports ${ }^{19}$. For both feminist representatives and members of the women's movement, Sernam's involvement with the bill thus created crucial opportunities for them to participate in the policy process. Throughout the bill's three-year progress through the Congress, it was included in the extraordinary legislative sessions and was declared urgent at key moments.

\section{Strategic Framing and Negotiation}

In order to overcome conservative opposition to the bill in the Congress, Sernam's Minister agreed to a number of content changes that had the cumulative effect of shifting it toward a focus on the maintenance of family unity over protection of victims of abuse. Sernam's revisions to the bill, approved by the committees, increased the original bill's emphasis on non-incarceration options for dealing with cases of abuse, including community service work in addition to therapy. Most critically, the final version of the bill gave judges discretion over when, and if, to remove the aggressor from the home.

17. La Nación, January 19, 1991; Muñoz interview with the author, June 5, 2001.

18. The deputies held a press conference and declared, "The government is not respecting those minimal areas in which we can legislate" (El Fortin, January 19, 1991).

19. Among the organizations that testified before Congress on the bill were ISIS International, the Network Against Violence (a collective of feminist organizations focusing on violence against women), the Women's Institute of Santiago, the "Women's House" of Valparaíso, and the Santiago-based Women's Collective of La Florida. 
Feminists at the hearings insisted that women would not denounce abuse if the abuser remained in the home following the filing of charges, but Sernam's legal team argued that developing nonincarceration measures for responding to domestic violence would make it less likely that women would later drop the charges rather than see their partners sent to jail. Members of the feminist community widely criticized these changes to the original bill, arguing that the lack of victim protection under the new law would increase the danger to women who reported abuse. For example, Paulina Weber of $\mathrm{MEMCH}$ in Santiago ${ }^{20}$ blamed Sernam for altering the intra-family violence bill until it became:

[...] more educative than disruptive [to the marriage], to the point that if a man hits a woman, the man has to educate himself so that he'll stop beating the woman. It allows him to demonstrate that he won't continue to beat the woman; he's forced to submit to therapy so that he won't continue to beat the woman, but in no way should this imply that the couple ceases to function. In other words, the concept behind it is that the couple cannot be split apart, and it's recommended that the man be good and not beat the woman, and to the woman it's recommended that she have a lot of patience with the man, and this is where justice ends - it ends with the judge calling the parties together and giving the man a slap on the wrist and saying "behave yourself" to him, and saying "have patience" to the woman ${ }^{21}$.

Weber viewed the intra-family violence law as enshrining the "ludicrous" idea that a woman in such a situation must defend her marriage over her own life ${ }^{22}$. In addition, the resulting law was widely criticized for its failure to secure the funding necessary for implementation.

\section{Feminist Learning in the Wake of the Intra-Family Violence Law}

The perception by many feminists that Sernam's involvement with domestic violence legislation ultimately resulted in a conservative and largely unenforceable law shaped their expectations about future cooperation with the Ministry. Feminist organizations, already beset by external and internal pressures, decreased their public presence in the wake of the passage of the VIF law. Feminist representatives in Congress, stung by the public battle with the Ministry over ownership of the bill, and recognizing the Ministry's resistance to support more controversial feminist issues, such as abortion and divorce, resigned themselves to the need to legislate independently of Ministry support.

20. MEMCH (Movement for the Emancipation of the Chilean Woman) is one of the oldest and most respected feminist organizations in Chile.

21. Interview with the author, March 25, 1997.

22. Ibid. 
Despite the weaknesses of the VIF law, it laid the groundwork for later attempts to improve the law. In 1999, two feminist deputies, Adriana Muñoz (now with the PPD) and fellow party member Maria Antonieta Saa introduced a motion to strengthen protection for victims of domestic abuse and increase funding for the law (Law 20.066). This bill, which passed the Congress in 2005, explicitly criminalizes domestic violence and allow for rapid removal of the aggressor from the home. Together with the new Family Tribunals (created in 2005), the new law should allow for a more rapid processing of abuse complaints and a higher rate of convictions ${ }^{23}$.

\begin{abstract}
Abortion
Significance of the Bill

The Therapeutic Abortion bill illustrates the enduring challenge of tackling controversial policy issues in the absence of executive support and in the face of entrenched cultural opposition. Sernam refused to support congressional efforts to decriminalize therapeutic abortion, and congressional representatives alone lacked the institutional strength and political support to overcome widespread opposition to the bill from the Right, conservative Christian Democrats, and the Catholic Church. The lack of institutional cooperation on the bill, together with poor political strategizing on the part of the bill's sponsors, led to the failure of the bill in congressional committee. Thirteen years after the failure of the therapeutic abortion bill, representatives introduced a similar initiative into Congress, indicating an increasing willingness among representatives across the political spectrum to reopen debate on the issue.
\end{abstract}

\title{
Institutional Cooperation
}

Therapeutic abortion was legal in Chile from 1936 until 1989, when it was criminalized in one of the last acts of the outgoing military government. Today, abortion is illegal in Chile even if the mother's life is at stake. Nevertheless, enforcement of the abortion law is relatively weak, and the abortion rate in Chile is high ${ }^{24}$. Public

23. Jen Ross, 2004. "Chileans Facing up to Domestic Violence." Women's eNews, Feminist.com, December 31.

24. It is difficult to estimate the rate of abortion accurately, given its illegality. The Guttmacher Institute (www.guttmacher.com) estimates that one-third of pregnancies in Chile end in abortion. However, while there is wide acceptance of the existence of significant rates of abortion in Chile, some researchers have also argued that the relative reliability of Chilean data compared to that of other Latin American countries may lead to an overestimation of Chile's abortion rate. 
opinion polls since the transition support the decriminalization of therapeutic abortion ${ }^{25}$.

Socialist Deputy Adriana Muñoz was among those members of the political Left who had been calling for liberalization of abortion laws since before the transition to democracy, and, following her election to the Chamber of Deputies, she introduced a bill to re-legalize therapeutic abortion in 1991. The bill was co-signed by four fellow party members, Armando Arancibia, Carlos Smok, Juan Pablo Letelier, and Carlos Montes, and the following month Humanist/Green Party Deputy Laura Rodriguez also signed on. The bill itself was a mere two sentences long: "Only toward therapeutic ends may a pregnancy be interrupted. To undertake this intervention the documented opinion of two medicalsurgeons is required" ${ }^{26}$. Socialist Deputy Adriana Muñoz explained:

The fact that we debate [abortion] doesn't mean that abortions will increase in Chile or that we are against life. What we are doing is recognizing a fact of reality and preventing legislation from becoming outmoded, as it is now, when there exists a law which penalizes abortion and more than 150,000 women abort every year ${ }^{27}$.

Despite the Socialist Party's position in favor of decriminalization, there was no party-level support for the bill. The therapeutic abortion bill aroused enormous opposition from the Catholic Church and from conservative political sectors, including Christian Democrats, and many Socialists felt that to be identified with such a bill early on would hurt the party's future electoral chances, especially at the presidential level. Therefore, the party did not issue any statements in support of Muñoz when she was vilified in the press and failed to support her candidacy for the 1994 congressional elections ${ }^{28}$. Public support from interested feminist organizations, such as the Open Forum on Health and Reproductive Rights ${ }^{29}$, also failed to materialize. Feminist organizations

25. For example, a 1989 CERC survey found that $75.8 \%$ of respondents "believe that the interruption of a pregnancy should be legally permitted when the mother's life is at risk or the child would be born deformed. Similar survey results were found by APROFA-CERC (1989, 1990), DIAGNOS (1984), and FLACSO (1988). For more recent analysis of public opinion on abortion, see Blofield 2006.

26. Bill \# 499-7, p. 1 .

27. From interview in La Nación, June 27, 1991.

28. Muñoz blames her failure to be re-elected on the visible lack of party support she received in her district, and she believes the lack of support stemmed from the introduction of her therapeutic abortion bill against the wishes of the party leadership. Muñoz switched her party affiliation to the PPD and was re-elected to the Chamber of Deputies in 1998.

29 In 1985 an alliance of NGOs, the, was formed to focus attention on the issue of abortion and to coordinate movement action in this area. But given the strength of social and political forces opposing the decriminalization of abortion laws, it has been extremely difficult to date to promote public debate on the issue, and abortion has not been a focal point of mobilization of the women's movement. 
complained that Muñoz had not consulted with them in the development of the bill ${ }^{30}$.

In the absence of broad party support for the legislation, the bill would only survive with executive support. As expected, given the Christian Democratic Party's official position in opposition to abortion, Sernam (headed by Christian Democrat Soledad Alvear) also refused to support the proposal.

\section{Strategic Framing and Negotiation}

The therapeutic abortion legislation was framed as a return to Chile's previous law. Anticipating the types of arguments that would be mounted against the bill, Muñoz downplayed references to individual rights as a defense of decriminalization. Taking the existence of abortion as a given, the preamble to the bill concentrated instead on the harm done to the family as a result of the complete ban on abortion, namely:

The numerous psycho-social consequences for children and for the family in general, which result from the loss of the life or health of the mother, which not only destroys a marriage but also implies a traumatic experience for the children, who will suffer a lack of affection because a person fundamental to their formative development, in the sense of transmitting values, knowledge, etc., has disappeared. The gravity of the situation of small children due to the absence of the mother, [because she is] poor and/or single or deceased, leads to [the children's] probable "internment" in a Children's Home... homelessness, or in the majority of cases, life in foster homes ${ }^{31}$.

The proposal thus conceived of women who would seek abortions as already mothers, who needed to be able to care for the children they already had. In this way, the bill frames abortion as a public health issue, rather than a matter of women's rights.

\section{Feminist Learning in the Wake of the Therapeutic Abortion Bill}

Given the lack of institutional support for the therapeutic abortion bill, both from Sernam and within the Congress, its failure was overdetermined. Nevertheless, feminists took a number of lessons from the experience. In the short term, they realized the futility of attempting to legislate on such a controversial issue, in the absence of visible public support for policy reform. Feminists also gained experience framing their proposals to try to overcome conservative opposition.

30. Author's interview with Forum member Fanny Berlogosky, Santiago, June 1997.

31. Chamber of Deputies, Legislative session 41a, September 17, 1991, p. 4087. 
The introduction of the therapeutic abortion bill also sparked a conservative legislative backlash, with the introduction of several legislative proposals aimed at increasing the penalties for providing and procuring an abortion ${ }^{32}$. The introduction of the original bill, together with conservative counter measures, allowed for the emergence of public debate on some aspects of the issue of abortion, such as the obvious class bias in prosecuting women who abort ${ }^{33}$. While stopping short of advocating decriminalization of abortion, Sernam's second Minister, Christian Democrat Josefina Bilbao, spoke out publicly against the criminal prosecution of women who abort, as did other Christian Democratic leaders, such as then-Deputy Mariana Aylwin.

More significantly, the political and cultural terrain in Chile may have evolved to the point that another attempt at legislating this issue may find more success. In 2003 and 2004, bills were introduced to decriminalize therapeutic abortion and to establish legal protections for reproductive rights (bills 3702 and 3197, respectively). Particularly noteworthy about these most recent attempts is the fact that both bills framed the issues in explicitly "pro-family" terms (the therapeutic abortion bill closely mirrors Muñoz's original effort), and both were introduced by a coalition of representatives from the Socialist Party, the PPD, the PDC, and Renovación Nacional. As of this writing, the executive has yet to respond to either initiative.

\section{Divorce}

\section{Significance of the Bill}

Finally, the Divorce Law illustrates the potential to pass fundamental policy reform even on controversial policy issues, if feminists can successfully strategize around institutional constraints and cultural opposition. Lacking executive support from Sernam for the 1995 proposal, congressional representatives were forced to agree to significant content changes to gain the political support needed to keep the proposal alive in Congress. In the wake of Lagos' election as President, Sernam's leadership began to actively support the divorce legislation. This institutional pressure in favor of reform allowed representatives to press for the passage of more sweeping legislation.

With the legalization of divorce in Ireland in 1996, Chile became the only nation to lack some type of legal divorce. Divorce a la Chilena refers to

32. See Haas (2000).

33. It is disproportionately poor women, who must resort to unsafe abortions, who have medical complications that then prompt police investigation and prosecution. See Casas 1996. 
the one method of obtaining a civil annulment: committing perjury before the Civil Registrar by claiming that one lied on some aspect of the original marriage license, thereby voiding the contract. Efforts to legalize divorce focused on the recognition of the widespread use of perjury to gain civil annulments and the need to have the State replace this informal system with a set of logical and equitable legal guidelines to regulate the dissolution of marriage.

\section{Institutional Cooperation}

The Left introduced several divorce bills in 1991, 1993 and 1994. All three bills referred to individual rights guaranteed by the constitution as well as the fraudulent system of annulments, and outlined a liberal divorce regime. They sought to guarantee divorce in cases of mutual consent, aggravated circumstances, and separation of the couple for over one year. None of the bills garnered support beyond the Left, and none was debated in committee.

While the leadership of Sernam criticized the system of fraudulent annulments and expressed informal support for the idea of divorce, prior to the Lagos administration, Sernam refused to offer formal support for divorce legislation. Despite Sernam's reticence and the vocal opposition to reform from the Right and the Chilean Catholic Church ${ }^{34}$, wide support for reform within the Left and growing support among sectors of the PDC, contributed to a more auspicious political context for reform on this issue than was the case with abortion. Representatives believed that, with enough strategic framing of a proposal and with concerted efforts to reach out to moderates beyond the Left, divorce legislation was possible, even in the absence of executive support.

\section{Strategic Framing}

The 1995 divorce bill is qualitatively different from its predecessors in content and, as a result, in the breadth of political support for the measure. Introduced by two Christian Democratic Deputies with broad support from the Left and even a few representatives from Renovación Nacional, the "New Civil Marriage Law" made major concessions to conservatives on content and also reframed the bill to be more "profamily". The preservation of family unity as a general rule was the foundation of the new bill. For example, a mandatory five-year waiting period for a divorce was added to the bill, and judges were given broad powers to deny requests for divorce. Combined with the closing of the annulment loophole, the 1995 bill in effect made divorce much more

34. See Haas (1999) for a detailed analysis of the role of the Chilean Church in the divorce debate. 
difficult to come by than under the current system, and this allowed Christian Democrats (and members of the Right) to argue that in fact the bill would strengthen the family. The very title of the 1995 bill reflects efforts to avoid even the word "divorce". As explained by Christian Democrat Ignacio Walker, one of the bill's sponsors, "It's not a divorce bill. It's a marriage bill" (Walker, 2000). Feminist representatives explicitly recognized the strategic tradeoffs necessary to propel the bill through the Congress. PPD Deputy Antonieta Saa explained:

It's not a bill from one deputy or two deputies from the same party, but rather, this proposal reflects a process of negotiation in the construction of the bill with deputies from all the parties except the UDI... And in this regard I had to set aside my own desire to draft a bill which would allow divorce in cases of mutual consent, but I did it thinking that if we gained this alliance, we would, at the very least, begin an historical process in the country: a law, which was the fundamental thing ${ }^{35}$.

After passage of the bill by the Chamber in 1997, it was sent to the Senate where it lay buried in a hostile Justice Committee until 2002. The critical factor that propelled the bill through the Senate was the introduction of executive pressure in support of the bill. Socialist Ricardo Lagos had promised during his presidential campaign to push for the legalization of divorce. Following his election in 2000, Lagos gradually became more aggressive in support of the legislation, and eventually forced the Senate to debate an executive-modified version of the bill. Sernam, led by Ministers Adriana del Piano (PPD; 2000-2003) and Cecilia Pérez (Independent; 2003-2006), and the Ministry of Justice, led by former Sernam Minister Soledad Alvear (PDC), worked to update the Chamber bill.

Executive support allowed some of the previously abandoned aspects of earlier divorce bills to be reintroduced. The executive-modified version added needed protections for children. Most significantly, the final version of the bill reinstituted divorce by mutual consent, although couples must be separated for a year before filing for divorce, and judges make take up to an additional three years to complete the filing. Couples must also submit to mandatory mediation. The divorce bill passed the Congress and was signed into law in May 2004.

\section{Feminist Learning in the Wake of the Divorce Law}

The Divorce Law illustrates the potential to pass fundamental policy reform even on controversial policy issues, if feminists can successfully strategize around institutional constraints and cultural opposition. We can identify two phases to the policymaking dynamic on this legislation.

35. From interview with the author, January 15, 1997. 
In the first phase, the absence of institutional cooperation necessitated significant compromises on the content of the bill. In the second phase, strong executive support allowed representatives to renegotiate more fundamental policy reform. The divorce bill illustrates the clearest example of learning by feminist representatives. Compared with previous divorce bills, feminist representatives approached the 1995 divorce bill much more strategically, negotiating with the conservative opposition early in the bill's development. Major concessions on the bill's content, together with a conscious effort to frame the topic within a pro-family discourse, allowed feminist representatives to build support for the bill early in the legislative process, which was a key factor in the bill's passage in the Chamber of Deputies in 1997. Executive support served to reactivate the bill in the Senate, and most importantly, to pass a more progressive version of the bill than the original congressional proposal.

\section{Conclusions}

The return of electoral democracy in 1989 ushered in a new institutional structure to Chilean politics. The analysis of feminist policymaking since the transition demonstrates that political actors do not automatically comprehend the most effective strategy for gaining political advantage in a given institutional context. Rather, successful political strategy evolves over time, with repeated political interaction. In Chile, both institutional structure and cultural opposition to feminism constrain the opportunities for progressive policymaking on women's rights. Feminists working within the political system have learned that executive support is a critical factor for legislative success, but that this sponsorship often comes at the cost of losing ownership of legislative initiatives and control over their content. Framing feminist proposals in language that appeals to cultural conservatives and compromising on the content of legislative initiatives can help build support for passage, but the resulting laws may be inoperable or, in some cases, worse than the preexisting policy. Over the past sixteen years, feminists in Chile have learned to strategize more effectively within this complex political landscape, and charting the legislative histories of their proposals on domestic violence, abortion and divorce illuminates this process.

The recent increase in congressional initiatives, and particularly in crossparty support for legislation on abortion and reproductive rights, seems to provide further evidence of the diffusion of feminist ideals noted in recent research by scholars such as Alvarez (1999) and Ríos Tobar (2003). Interest in and support for feminist policy has clearly expanded beyond the small core of feminist representatives responsible for most feminist initiatives in the first administrations. The election of Michelle Bachelet 
to the presidency, and the appointment of women to half the executive cabinet, including Christian Democrat Laura Albornoz to head Sernam, is further indication of the increasing influence of feminism in Chilean politics. The passage of an electoral quota law, a central political goal for Bachelet and Albornoz, would create further opportunities for women, and feminists in particular, to impact policymaking.

Important and relevant on its own terms, the Chilean case also adds to our knowledge of gender and politics and expands our understanding of the policymaking process in different political, institutional and cultural contexts. The institutional and cultural factors I analyze in Chile have applicability to Latin America more broadly, where intra-governmental power struggles and conservative political forces have a long history.

\section{Works cited}

Álvarez, Sonia E. "Latin American Feminisms 'Go Global': Trends of the 1990s and Challenges for the New Millennium". In Sonia E. Álvarez, Evelina Dagnino and Arturo Escobar, eds. Cultures of Politics, Politics of Culture: Re-visioning Latin American Social Movements. Boulder CO: Westview, 293-324.

Baldez, Lisa. 2001. "Coalition Politics and the Limits of State Feminism." Women and Politics 22 (4): 1-28.

1999. “La Política Partidista y los Límites del Feminismo de Estado en Chile". In Paul Drake and Iván Jaksic, ed. El Modelo Chileno: Democracia y Desarrollo en los Noventa. Santiago: LOM, 407-433.

Baldez, Lisa and John Carey. 1999. "Presidential Agenda Control and Spending Policy: Lessons from General Pinochet's Constitution". American Journal of Political Science 43 (1): 29-55.

Blofield, Merike H. 2006. Moral Politics. New York: Routledge.

Blofield, Merike H. and Liesl Haas. 2005. "Defining a Democracy: Reforming Laws on Women's Rights in Chile". Latin American Politics and Society 47 (3), Fall: 35-68.

Carey, John. 1999. "Parties, Coalitions, and the Chilean Congress in the 1990s. In Scott Morgenstern and Benito Nacif, ed. Legislative Politics in Latin America. New York: Cambridge Press, 222-253.

Casas, Lidia B. 1996. Mujeres Procesadas por Aborto. Santiago, Chile: LOM.

Chuchryk, Patricia M. 1994. “From Dictatorship to Democracy: The Women's movement in Chile". In Jane S. Jaquette, ed. The Women's Movement in Latin America: Participation and Democracy, Boulder, CO: Westview Press, 65-108.

Craske, Nikki. 1999. Women and Politics in Latin America. New Brunswick: Rutgess University Press.

Franceschet, Susan. 2003. "States and Women's Movements: The Impact of Chile's Servicio Nacional de la Mujer on Women's Activism". Latin American Research Review 38 (1): 9-40. 
Grau, Olga, Eugenia Brito, Riet Delsing, and Alejandra Farías, ed. 1997. Discurso, Genero y Poder: Discursos Públicos: Chile 1978-1993. Santiago, Chile: LOM-ARCIS.

Guzmán, Virginia, Eugenia Hola and Marcela Ríos. 1999. “Interlocución Estado y sociedad en la implementación del plan de Igualdad de oportunidades para las mujeres". Santiago, Chile: IEM.

Haas, Liesl. 2001. "Changing the System from Within? Feminist Participation in the Worker's Party in Brazil, 1989-1995." In Victoria Gonzalez and Karen Kampwirth (eds.), Radical Women in Latin America: Right and Left. University Park, PA: Pennsylvania State University Press, 249-272.

2000. "Legislating Equality: Institutional Politics and the Expansion of Women's Rights in Chile". Ph.D. diss. University of North Carolina.

1999. "The Catholic Church in Chile: New Political Alliances". In Latin American Religion in Motion, ed. Christian Smith and Joshua Prokopy. New York: Routledge, 43-66.

Htun, Mala. 2003. Sex and the State: Abortion, Divorce and the Family Under Latin American Dictatorships and Democracies. New York: Cambridge Press.

Londregan, John B. 2000. Legislative Institutions and Ideology in Chile. New York: Cambridge Press.

Macaulay, Fiona. 1998. "Localities of Power: Gender, Parties and Democracy in Chile and Brazil". In Afshar, Haleh, ed. Women and Empowerment: Illustrations from the Third World. New York: St. Martin's Press, 86-109.

Magar, Eric, Marc R. Rosenblum, and David Samuels. 1998. "On the Absence of Centripetal Incentives in Double-Member Districts: The Case of Chile". Comparative Political Studies 31 (December): 714-739.

Matear, Amy. 1996. “Desde la protesta a la propuesta: The Institutionalization of the Women's Movement in Chile". In Elizabeth Dore, ed. Gender Politics in Latin America. New York: Monthly Review Press, 84-100.

Norton, Noelle H. 1999. “Uncovering the Dimensionality of Gender Voting in Congress". Legislative Studies Quarterly XXIV, 1, February: 656-686.

Pickup, Francine. 2001. Ending Violence Against Women: A Challenge for Development and Humanitarian Work. London: Oxfam.

Ríos Tobar, Marcela. 2003. "Chilean Feminism(s) in the 1990s: Paradoxes of an Unfinished Transition". International Feminist Journal of Politics 5 (2), July: 256-280.

Schild, Verónica. 1998. "New Subjects of Rights? Womens Movements and the Construction of Citizenship in New Democracies". In Álvarez, Sonia, Arturo Escobar and Evelina Dagnino, eds. Politics of Culture, Culture of Politics: Re-Visioning Latin American Social Movements. Boulder, CO: Westview Press, 93-117.

Siavelis, Peter. 2000. The President and Congress in Postauthoritarian Chile: Institutional Constraints to Democratic Consolidation. University Park, PA: Penn State Press.

Valdés, Teresa and Alicia Frohmann. 1993. Democracy in the Country and in the Home: The Women's Movement in Chile. Santiago, Chile: Flacso. 
Valenzuela, María Elena. 1999. “El desafío de hacer política feminista desde el estado". Mujer/Fempress, edición especial, "Feminismo fin de siglo", Santiago, Chile: Fempress.

Waylen, Georgina. 2000. “Gender and Democratic Politics: A Comparative Analysis of Consolidation in Argentina and Chile". Journal of Latin American Studies 32: 765-793.

1997. “Women's Movements, the State and Democratization in Chile: The Establishment of SERNAM". In Anne Marie Geotz, ed. Getting Institutions Right for Development. London: Zed Books, 90-104. 
- 